\title{
Should Some Limits Be Set to the Harsh Realities Represented in Young Adult Fiction?
}

\author{
Aitor Ibarrola Armendariz \\ Department of Modern Languages and Basque Studies, University of Deusto, Spain
}

Copyright $(2016$ by authors, all rights reserved. Authors agree that this article remains permanently open access under the terms of the Creative Commons Attribution License 4.0 International License

\begin{abstract}
Sherman Alexie's novel for young adults The Absolutely True Diary of a Part-Time Indian (2007) won several book awards, including the Amazon.com Best Book of the Year and the National Book Award for Young People's Literature. Reviewers praised the raw feelings and the intelligent humor that Alexie shows in his portrayal of a 14-year-old Native American boy who faces many of the ordeals that the author himself experienced as an adolescent: illness, bullying, alcoholic parents, racism, etc. His protagonist, Arnold Spirit Jr., shares with other young heroes such as Huck Finn and Holden Caulfield an urgent desire to escape, in his case from the constraints forced upon him by life on the Spokane Reservation. Interestingly, despite the immense courage and honesty that the character exudes, the book has become the target of fierce criticism as it is said to depict violence, sex, and xenophobia in ways that will hurt the sensibilities of young readers.
\end{abstract}

Keywords YA Fiction, Native Americans, Sherman Alexie, Problem Novels, Censorship

\section{Introduction}

Sherman Alexie's The Absolutely True Diary of a Part-Time Indian (2007) was the author's first foray into the young adult (YA) genre; yet, it could easily be evinced that he succeeded in mastering the form of this type of fiction in one single book. Probably the most convincing evidence to show that his incursion into the genre was fortuitous is the number of awards that the book received right after its publication. Among them, the National Book Award for Young People's Literature, the Amazon.com Best Book of the Year, and the Boston Globe-Horn Book Award could be mentioned. Most reviewers agreed that it was the raw feelings and the intelligent humor that Alexie displays in his portrayal of a fourteen-year-old Native American boy that gave the book its riveting character. Bruce Barcott [1], for example, noted that working in the voice of the adolescent protagonist forced the author "to strip everything down to action and emotion, so that reading becomes more like listening to your smart, funny best friend recount his day [...]" Indeed, the most outstanding quality of the book is that Alexie manages to reproduce the way of talking of his teenage narrator with all the spontaneity and coarseness that one would expect from a boy of that age. In a similar line, Diane Samuels [2] concluded in the Guardian that "Opening this book is like meeting a friend you'd never make in your actual life and being given a piece of his world, inner and outer. It's humane, authentic and, most of all, it speaks." Like most YA fiction, The Absolutely True Diary (TATD) is characterized by the dashing and memorable voice of the narrator, the shocking and thorny issues that it covers, a sharp sense of humor, and the accuracy and authenticity with which the-often trying-events are conveyed. [cf. 3, p61-65]

The protagonist of the novel, Arnold Spirit Jr., is faced with many of the trials that the author himself experienced in his transition from childhood into adulthood: poverty, bullying, a dysfunctional family, racism, etc. "Junior," as he is widely known on the reservation, shares with other classic heroes such as Huck Finn and Holden Caulfield a profound desire to escape from the constraints that, in his case, life on the Spokane Reservation impose on him. Like those earlier wanderers, Junior is seen to struggle with his wish to remain true to himself while, at the same time, trying to find his place as a member of a community - or more. As Roberta Trites has maintained, much YA fiction dives into these tricky identity questions, since the "protagonists must learn about the social forces that have made them what they are." [4, p3] In Junior's case, he grows increasingly aware of the limitations that his peoples' past and current conditions on the reservation set for his future. Thus, he will need to embark on a hazardous - but also illuminating — journey that will allow him to see beyond the narrow confines that those people closest to him mark off for his life. Of course, coming to the conclusion that the context in which you are growing up offers little hope for the realization of your dreams and ambitions is not pleasant at all. However, as will be seen below, Junior manages to survive the pains of harrowing events such as the loss of his pet dog, Oscar, of his beloved 
Grandma and smart elder sister, Mary Runs Away or his visceral brawls with his best friend, Rowdy. Most likely, Alexie's greatest achievement in this bleak tale of unremitting woe is to move his readers to sympathy and understanding as they get to see Junior clawing his way out of a seemingly inescapable fate. [cf. 5]

In spite of the generally positive reception, the laudatory reviews, and the prestigious literary prizes the book was awarded, a number of voices were also raised to criticize Alexie's crude representation of issues such as bullying, xenophobia, sex or, even, the violent deaths of some of the characters. Some parents, school boards, and libraries believed that such explicit renditions of the squalor and anguish present on Indian reservations were utterly "inappropriate" for the delicate palates of young readers. Notice, for instance, Junior's reflections after the rather inane death of one of his father's best friends: "And, after Eugene's funeral, I agreed with her [Euripides' Medea]. I could have easily killed myself, killed my mother and father, killed birds, killed the trees, and killed the oxygen in the air. / More than anything. I wanted to kill God.” [6, p173] While it is true that some of the explicit violence, sexual references, and profane language may seem distressing even to adult readers, the second half of this article will discuss the wisdom - or lack of it - in censoring literary works that present such harsh aspects of contemporary life. Alexie, of course, has taken his own belligerent position on the matter, but other specialists in the field of young adult fiction, such as James Blasingame (2007) and Steven Wolk (2009), have also enriched the debate-or should we say controversy - with stimulating ideas, advocating in most instances for the author's freedom to deal with the issues in ways that connect with the younger generations.

\section{Playing with the YA Genre in Alexie's Fictional Autobiography}

Clearly one of the reasons why Alexie found it relatively easy to relate to the voice and the general attitude of his protagonist was the fact that much of the background information about Junior's childhood provided in the early chapters of the novel is directly based on the author's own experiences on the Spokane Reservation in Wellpinit, WA. Like Junior, Sherman was also born with hydrocephalus_- "I was born with water on the brain," $[6$, p1] the opening sentence of the novel intimates - and suffered from headaches and a number of sight impediments. Due to his oversized skull, the author was often teased by his classmates in school and became the object of bullying: "My head was so big that little Indian skulls orbited around it. Some of the kids called me Orbit. And other kids just called me Globe. The bullies would pick me up, spin me in circles, put their finger on my skull and say, 'I want to go there'." [6, p3] Besides his serious health problems, another aspect that Alexie's childhood shares with that of his hero is the poverty and dejection of the social context in which he grew up:
It sucks to be poor, and it sucks to feel that you somehow deserve to be poor. You start believing that you're poor because you're stupid and ugly. And then you start believing that you're stupid and ugly because you're Indian. And because you're Indian you start believing you're destined to be poor. It's an ugly circle and there's nothing you can do about it. [6, p11, italics in original]

In the speech Alexie gave when presented with the Boston Globe Horn Book award, he stated in regard to the autobiographical nature of the book that "If I were to guess at the percentage, it would be about seventy-eight percent true." [7, p27] Like Junior, the author also chose to leave the reservation to attend high school in Reardan High, a school located in a rich farm town, where he was the only Indian boy-except for the school team's mascot. Although mostly based on Alexie's dreadful experiences on and off the reservation, it is also true that he occasionally introduces slight modifications to make his protagonist's situation even more poignant. Thus, for example, when Junior learns that he has been given the same geometry textbook that his mother used thirty years before, instead of hurling the book against the wall, as Sherman allegedly did, he throws it at his geometry teacher, Mr. P: "My school and tribe are so poor and sad that we have to study from the same dang books our parents studied from. That is absolutely the saddest thing in the world." [6, p31] All things considered, it could be said that, as the author himself has admitted, although TATD comprises many of the real-life experiences he had as a teenager, they are told by an Indian kid who proves to be much smarter and kinder than he himself was at that age, a fact that made the novel "easier to write." [6, Interview np]

As pointed out above, although TATD was Alexie's first inroad into the YA genre, one can easily argue that the author-probably assisted by his editor, too-managed to encompass in the novel many of the features and thematic lines one expects to find in this kind of fiction. On the one hand, the book is packed with events and problems that adolescents can immediately identify with: being different and bullied, feeling ignored by one's parents, losing friends, etc. Mr P sums up some of these problems when he visits Junior after he is suspended from school for hitting him with the book: "'You've been fighting since you were born,' he said. 'You fought off that brain surgery. You fought off those seizures. You fought off all the drunks and drug addicts. You kept your hope. And now, you have to take your hope and go somewhere where other people have hope'." [6, p43] The old teacher's words open the young hero's eyes to both the sadness and lack of prospects that have dominated his childhood and the need to seek a different future elsewhere. Not only are young readers likely to be enthralled by the fast-paced and believable action in Junior's coming-of-age adventures, but the story is framed in language that they can understand and connect with at once. The first-person narrator has a voice that perfectly conveys the kind of anger and confusion that govern most of his experiences. This, for 
instance, is how he describes the reaction of his new fellow students at Reardan High on the first day of school: "Those white kids couldn't believe their eyes. They stared at me like I was Bigfoot or a UFO. What was I doing at Reardan, whose mascot was an Indian, thereby making me the only other Indian in town?" [6, p56] According to James Blasingame, if a YA book aspires to succeed among adolescent readers, it needs to contain characters and dilemmas that they can relate to real situations they have encountered. [8, p11] Despite being rooted in one specific socio-cultural context, TATD clearly brings together many contemporary issues (bullying, alcohol abuse, family conflicts and so on) in an emotionally honest voice that lends them universality. One does not need to be a Native American young man living on a reservation in order to understand the kind of outrage and impotence that we often hear in Junior's voice.

Now, while recognizing that Alexie's novel incorporates many of the characteristics that are to be found in most of the examples of YA fiction-such as precise socio-cultural details, lively and authentic dialogues, memorable characters and an effective voice-, it must also be noted that a few innovative elements make the reading even more exciting. For example, we learn early in the novel that Junior finds in drawing one of the few ways in which he can take a break from all the difficult experiences he is going through. His illustrations (or cartoons) do not only seem like the perfect supplement to his vigorous writing style, but they become an integral component of Junior's attempt to escape the confining horizons of life on the reservation: "So I draw because I feel like it might be my only chance to escape the reservation. I think the world is a series of broken dams and floods, and my cartoons are tiny little lifeboats." [6, p6] Figure 1, which shows a portrait of his parents as they might have been if someone had paid attention to their aptitudes and dreams, appears after two pages in which Junior has described to us the family's extreme poverty and his parents' problems with alcohol. [6, p12]

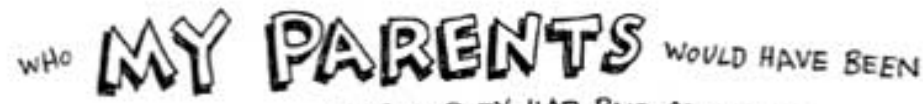 \\ IF SOMEBODY HAD PAID ATTENTION}

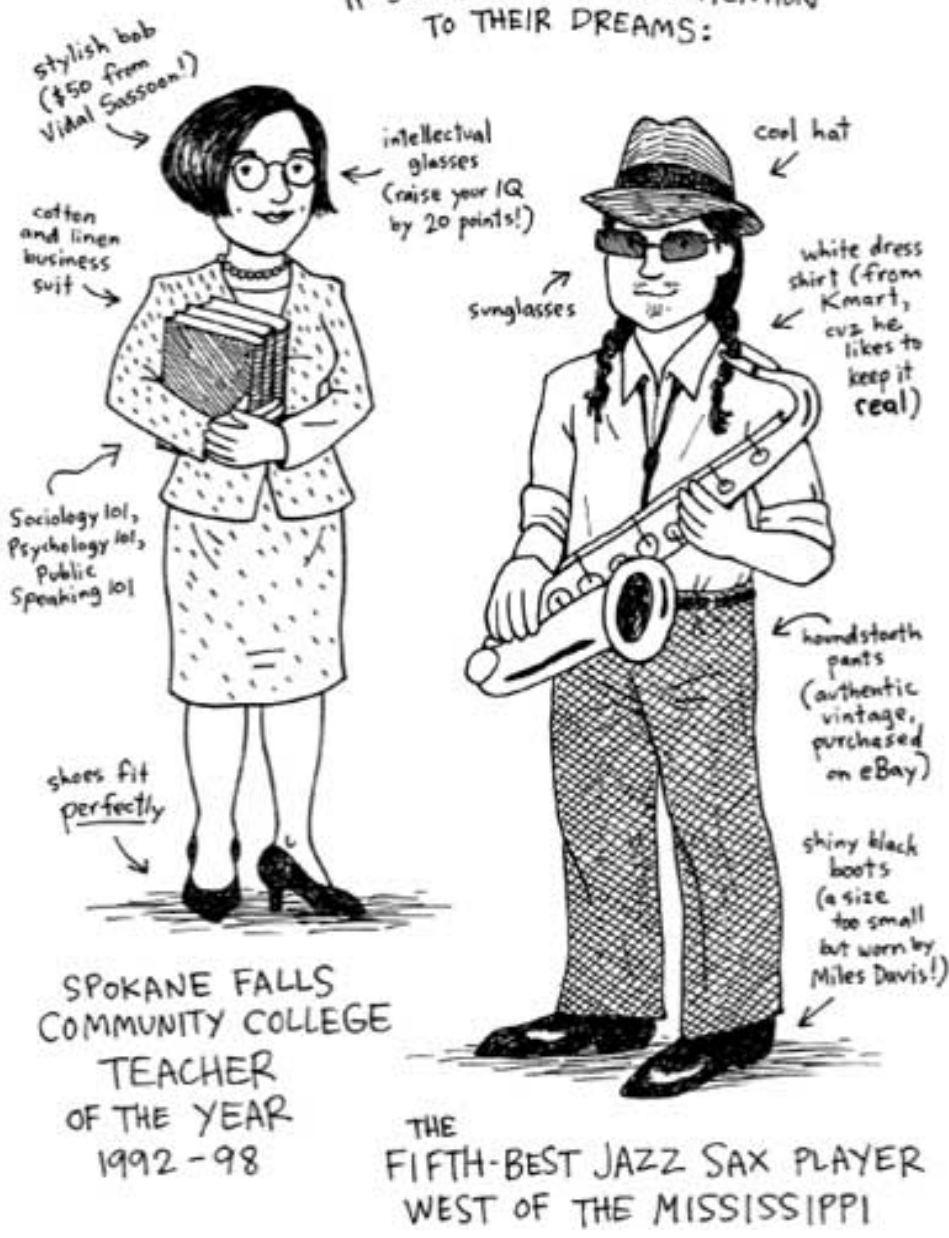

Figure 1. Junior's "potential" parents 
Besides the inspired and clever drawings - prepared for the book by artist Ellen Forney-, one other ingredient that may set TATD apart from more traditional YA fiction is a special brand of Native humor which incorporates heavy doses of weighty social criticism but, at the same time, may give a lighter touch to dramatic questions about one's ethnic identity, family conflicts or uncertain future. Late in the novel, after Junior goes with his parents to visit and clean the graves of some close friends and relatives he has lost throughout the story, he reflects on the hideous influence that reservation life is having on his people and concludes: "I realized that, sure, I was a Spokane Indian. I belonged to that tribe. But I also belonged to the tribe of American immigrants. And to the tribe of basketball players. And to the tribe of bookworms. / And to the tribe of cartoonists. / And to the tribe of chronic masturbators. / And to the tribe of teenage boys [...]." [6, p217] Despite the comic grain present in this long list, it is also important to underline that it contributes quite definitely to present Junior as a non-essentialist in identity matters. As some reviewers have pointed out, this may be one last element that distinguishes Junior from other (ethnic-minority) protagonists of YA novels, since while they usually reclaim and try to retain their "ethnic ties in order to find their true selves, Junior must separate from his tribe in order to preserve his identity." [9, p71]

\section{Where Should the Limits of Representation Be Set in YA Fiction?}

Notwithstanding the many strengths and innovations that readers have discovered in Alexie's novel, it must be recognized that responses to the book have not been consistently positive. Several teachers and reviewers expressed their concern that the treatment given to prickly issues such as sexuality, xenophobia or death was not befitting for young adults. Meghan Cox Gurdon, among others, has described recent teen fiction-in which she includes TATD — as "a hall of fun-house mirrors, constantly reflecting back hideously distorted portrayals of what life is." [10] According to this critic, young readers are unnecessarily exposed to pain, loss and brutality in these works that can hardly be said to make their lives easier or happier. Certainly, Alexie's YA novel is not characterized precisely by looking into the most cheerful aspects of teenage life: "There are all kinds of addicts, I guess. We all have pain. And we all look for ways to make the pain go away. / Penelope gorges on her pain and then throws it up and flushes it away. My dad drinks his pain away." [6, p107] Junior is not one who would try to candy-coat severe problems such as his new sweetheart's bulimia or his father's alcoholism. And it could even be contended that sometimes he may be excessively grim in depicting the realities on the reservation: "I read that [Euripides] and thought, 'Well, of course, man. We Indians have LOST EVERYTHING. We lost our native land, we lost our languages, we lost our songs and dances. We lost each other. We only know how to lose and be lost'." [6, p173] However, I would not agree with Gurdon when she claims that Alexie's ultimate aim-like that of much of the YA book industry - is simply "to try to bulldoze coarseness and misery into [...] children's lives." [10] Reading his YA novel in this light is to miss some of the most important implications of the text which are intimately linked to psychological resilience and social responsibility.

Alexie responded to the complaints raised by Gurdon and other reviewers in a post entitled "Why the Best Kids' Books Are Written in Blood," which appeared in the Wall Street Journal. As he saw it, all these endeavors to prevent young readers from learning about the harshest facets of contemporary life came "way, way too late." [11] From his point of view, it is rather ridiculous and hypocritical to pose as guardians of the youth when, in fact, children are exposed in the media and their daily lives to all sorts of aggressions that will inevitably interfere with their moral development. Alexie offered abundant evidence from his own childhood (violence, sex abuse, etc.) to show that ignorance of those realities did not help him much. Not only that, but he thought that removing his book from libraries and reading lists in states such as Missouri, Idaho or Wyoming was utterly unfair and nonsensical when he was constantly receiving letters and messages - often accompanied by cartoons, as well-from children and adolescents who told him that they had found his book helpful in overcoming the dilemmas and traumas that they were suffering from. If only because they learnt that they were not alone in facing those troubles, the book gave them some support and comfort that apparently their parents could not easily provide.

Two other momentous arguments could be used to rebut the platitudes of conservatives regarding the potential dangers of YA novels that represent current realities in too explicit terms. On the one hand, as Andrew Fersch and Steven Wolk, among others, have maintained, it is important that this kind of fiction, rather than blocking out and repressing childhood and teenage memories, should help adolescents to tackle the ordeals that they come across in their daily lives. In this regard, the latter has rightly observed that "Living a socially responsible life means understanding and acting to improve the many problems confronting the United States, especially involving culture, gender, economic class, and sexual orientation." [12, p667] Wolk believes that YA fiction has a critical role to play in terms of presenting these problems and, then, considering how particular individuals learn to cope and deal with them. In Fersch's opinion, "Alexie has written a novel that at once entertains and educates, and one that should be required reading for everyone, regardless of ethnicity, age, sex or race," [13] since it explores the "less-talked about types of discrimination" affecting teenagers. On the other hand, it should also be stated that Alexie is not the first YA fiction writer who has become the target of attacks from school boards, parents and public libraries. Writers such as Mark Twain, John Steinbeck, S.E. Hinton and J.D. Salinger faced similar criticism in their day and, in many cases, their works 
are lauded today as literary classics in the "problem novel" tradition. As Sarah Herz and Donald Gallo have shown, the themes and situational archetypes represented in YA fiction will not only help teenagers to deal with their tribulations in life, but will also encourage them to read more challenging and ambitious literary pieces that will permit them to widen their views on specific socio-cultural issues. [14, p64-66]

\section{Closing Remarks: Junior's Successful Journey}

TATD combines words and images to depict the brave journey taken by a Native American boy from a family and community ravaged - and often killed - by poverty and alcoholism to somewhere beyond the boundaries of his reservation where he can look for hope and a better future. This journey is by no means easy and it often involves breaking substantial barriers for a person of that age: estranging himself from his culture, losing touch with his best friend, adapting to a completely new environment and so on. Perhaps the most complicated part of Junior's transformation in the novel is his realization that once he has enrolled in Reardan High it will be impossible for him to think of one single place as "home": "Traveling between Reardan and Wellpinit, between the little white town and the reservation, I always felt like a stranger. / I was half Indian in one place and half white in the other. / It was like being Indian was my job, but it was only a part-time job. And it didn't pay well at all." [6, p118] It is no wonder that Junior is constantly assailed by doubts about which group he should pledge his allegiance to, since he finds appealing but also ugly elements in both: there is certainly much deprivation, violence and endemic alcoholism on the reservation, but there is racism, class-consciousness, and ineptitude in Reardan, too.

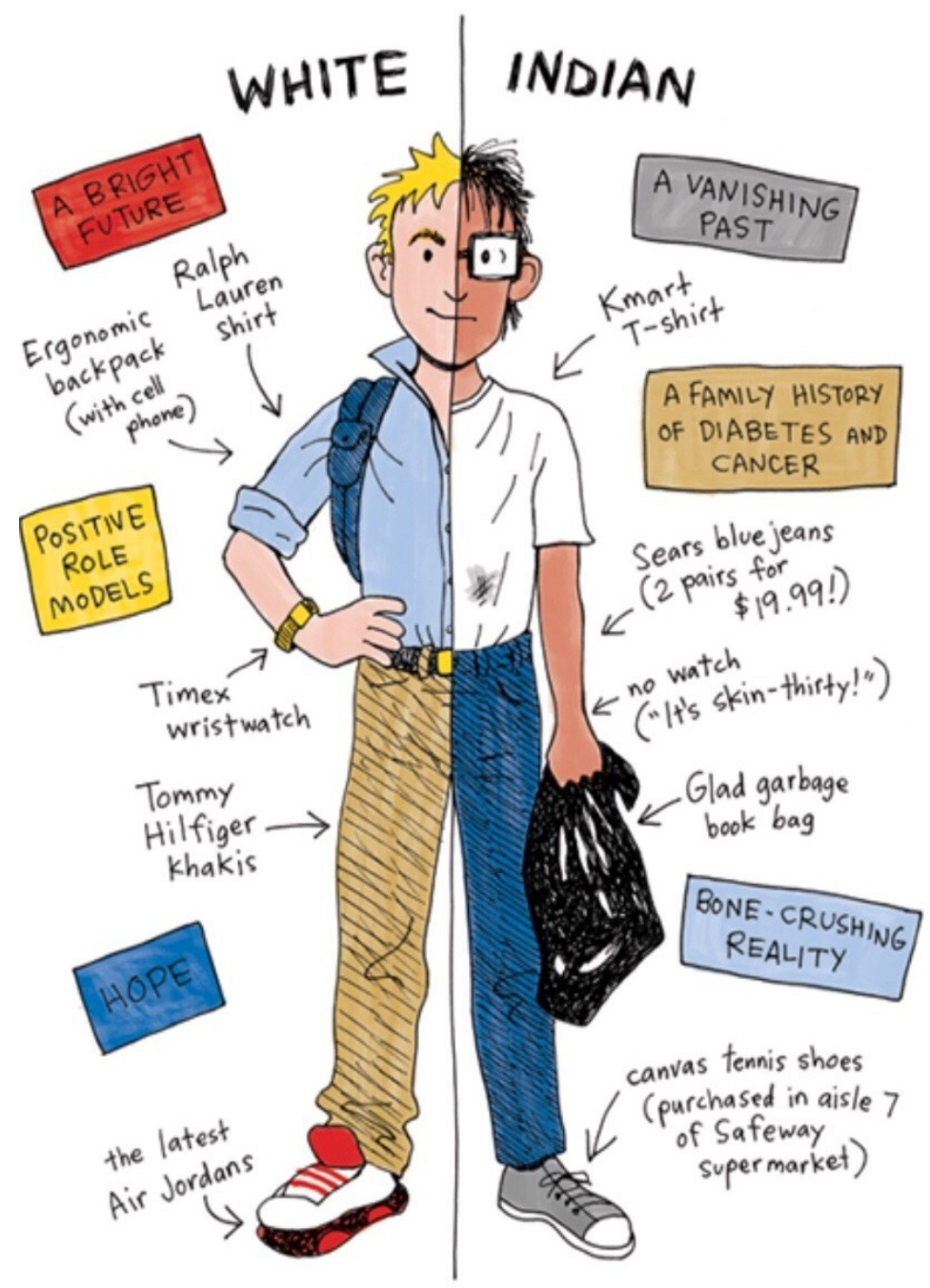

Figure 2. "Schizophrenic" Junior 
Junior's early days as a freshman at Reardan High are fraught with new trials that he will need to pass: he is afraid that he will be beaten up by the jocks, he is thought an interloper by some parents and teachers, and he soon realizes that his family cannot afford the kind of expenses other students have. Nevertheless, he perseveres and manages to make a handful of good friends - such as Penelope and Gordy-, he earns the confidence of his teachers, and even succeeds in becoming a player on the varsity basketball squad. Although the novel is fairly open-ended, it is quite clear that by the end of the story Junior does not see his future as a dead-end road, the way he did at the beginning: "All these white kids and teachers, who were so suspicious of me when I first arrived, had learned to care about me. Maybe some of them even loved me. And I'd been suspicious of them. And now I cared about a lot of them. And loved a few of them." [6, p212] Even if he will never have the same opportunities as his all-white friends at Reardan, he still believes that he has a chance if he tries hard enough.

Probably, parents and teachers who have been deeply disturbed by the gloomiest aspects of life on Indian reservations, the overt references to sexuality or the no-holds-barred quips that Alexie sporadically utters to talk about death or God, would also do well to look into the emotionally-inspiring changes that we see taking place in the novel. When a group of parents of incoming freshmen at Antioch High School wanted to pull Alexie's book from the school shelves and the curriculum due to its vulgar language, John Whitehurst, the chairman of the English Department, replied that Junior uses graphic language only to express his bitter feelings and to exchange taunts with his friends. But not only is he consistently courteous and respectful to adults and, particularly, to women, but his reflections are "filled with positive, life-affirming messages, and [have] an especially anti-alcohol message." [15] Truly, TATD is a work of fiction jammed full with invaluable lessons about how young men on the cusp of adulthood should deal with verbal and physical aggression, xenophobic attitudes, alcoholism, extreme grief and a long list of other socio-cultural disorders. If Junior's voice sometimes comes across as excessively coarse and inelegant, we should stop and consider what kind of misfortune or pain he is experiencing at that moment. Listen to him, for instance, when all his people get drunk at his elder sister's funeral:

Okay, listen, I'm not a cruel bastard, okay? I know that people were very sad. I knew that my sister's death made everybody remember all the deaths in their life. I know that death is never added to death; it multiplies. But still, I couldn't stay and watch all those people get drunk. I couldn't do it. If you'd given me a room full of sober Indians, crying and laughing and telling stories about my sister, then I would have gladly stayed and joined them in the ceremony.

But everybody was drunk. Everybody was unhappy. And they were drunk and unhappy in the same exact way. [6, p212]
According to Diane Samuels, TATD shares with some of the best works of YA fiction the fact that they "are like living organisms. They seem to breathe, laugh, weep, joke, confront, meet you eye to eye" [2]. Should we expect a teenager to address us in any other way? Not so, at least, if we really want him to come out with the quandaries that most trouble his inner self and if we wish to hear his honest response to the tensions that his relationships with others often cause. Alexie's True Diary can be said to offer both.

\section{REFERENCES}

[1] Barcott B. Off the Rez. New York Times [newspaper online]. 2007 Nov 11 [cited 2016 Jan 23]. Available from: http://www.nytimes.com/2007/11/11/books/review/Barcott3-t .html?_r $=0$

[2] Samuels D. A Brave Life. Guardian [newspaper online]. 2008 Oct 4 [cited 2016 Jan 23]. Available from: http://www.thegua rdian.com/books/2008/oct/04/teenage.sherman.alexie

[3] Cole PB. Young Adult Literature in the $21^{\text {st }}$ Century. New York: McGraw-Hill; 2009.

[4] Trites RS. Disturbing the Universe: Power and Repression in Adolescent Literature. Iowa City: University of Iowa Press; 2000 .

[5] Santos D. Civil Rights Book Club: The Absolutely True Diary of a Part-Time Indian. Civilrights.com [serial online]. 2010 Oct 1 [cited 2016 Jan 23]. Available from: http://www.civilri ghts.org/archives/2010/10/1073-indian-diary.html

[6] Alexie S. The Absolutely True Diary of a Part-Time Indian 2009. Illustrated by Ellen Forney. New York: Little, Brown; 2007.

[7] Alexie S. Fiction and Poetry Award Winner: The Absolutely True Diary of a Part-Time Indian. Horn Book Magazine. 2009 Jan;85(1):27-28. Available from: http://www.hbook.com/200 9/01/authors-illustrators/absolutely-true-diary-part-time-india n-author-sherman-alexies-2008-bghb-fiction-award-speech/

[8] Blasingame J. Books That Don't Bore 'Em: Young Adult Books That Speak to This Generation. New York: Scholastic; 2007.

[9] Publishers Weekly. Children's Book Review: The Absolutely True Diary of a Part-Time Indian. Publishers Weekly. 2007 Sep; 254(33): 70-71. Available from:http://www.publishersw eekly.com/978-0-316-01368-0

[10] Gurdon MC. Darkness Too Visible. Wall Street Journal [newspaper online]. 2011 June 4 [cited 2016 Jan 23]. Available from: http://www.wsj.com/articles/SB1000142405 2702303657404576357622592697038

[11] Alexie S. Why the Best Kids Books Are Written in Blood. Wall Street Journal [newspaper online]. 2011 Jun 9 [cited 2016 Jan 23]. Available from: http://blogs.wsj.com/speakeasy /2011/06/09/why-the-best-kids-books-are-written-in-blood/

[12] Wolk S. Reading for a Better World: Teaching for Social Responsibility with Young Adult Literature. J of Adolescent \& Adult Literacy. 2009 May; 52(8):664-673. 
[13] Fersch A. Book Review: The Absolutely True Diary of a Part-Time Indian. Vail Daily [newspapers online]. 2007 Oct 20 [cited 2016 Jan 23]. Available from: http://www.vaildaily. com/article/20071020/AE/71020009

[14] Herz SK, Gallo DR. From Hinton to Hamlet: Building Bridges between Young Adult Literature and the Classics. $2^{\text {nd }}$ edition.
Westport, CT: Greenwood; 2005.

[15] Fuller R. Some Parents Seek to Ban The Absolutely True Diary of a Part-time Indian. Chicago Tribune [newspapers online]. 2009 Jun22 [cited 2016 Jan 23]. Available from:http://article s.chicagotribune.com/2009-06-22/news/0906210159_1_part-t ime-indian-absolutely-true-diary-ban 